\title{
ANALISIS PENGGUNAAN JARINGAN LAN PADA PT USDA SEROJA KOTA BATAM
}

\author{
Pastima Simanjuntak, Cecep Sugianto, Imam Asyarie \\ Universitas Putera Batam, Indonesia.
}

\section{INFORMASI ARTIKEL}

Diterima Redaksi: 3 Februari 2018

Diterbitkan Online: 31 Maret 2018

\section{KATA KUNCI}

\section{Jaringan LAN, SPSS 21}

KORESPONDENSI

E-mail: p.lastria@gmail.com

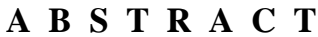

Usda Seroja Batam is one of the many companies that use computer network facilities. PT Usda Seroja Batam is in dire need of adequate network facilities to support two-way communication, namely employees with employees and employees with the company so as to create a good work environment to support all company activities. With the availability of a good computer network, data access speed is necessary. In accessing a data user or user wants fast access, but access speed is often constrained by the busy computer network used by all users or users in the company. The purpose of this research is to give perception how the use of LAN network at Usda Seroja Batam. The research method uses descriptive analysis that will obtain results from questionnaires that will be distributed to employees or network users in the company. From the results of descriptive analysis on the network, it will provide valuable information about the condition of a computer network.
\end{abstract}

\section{Latar Belakang}

Jaringan komputer merupakan sistem yang terdiri atas dua atau lebih komputer serta perangkat-perangkat lainnya yang saling terhubung. Media penghubung tersebut dapat berupa kabel atau nirkabel sehingga memungkinkan para pengguna jaringan komputer melakukan pertukaran informasi, seperti berbagi file, dokumen, data serta menggunakan perangkat keras atau perangkat lunak yang terhubung ke jaringan (Utomo, 2012: 1).

Local Area Network atau biasa disingkat LAN adalah jaringan komputer yang jaringannya hanya mencakup wilayah kecil; seperti jaringan komputer kampus, gedung, kantor, dalam rumah, sekolah atau yang lebih kecil. Saat ini, kebanyakan LAN berbasis pada teknologi IEEE 802.3 Ethernet menggunakan perangkat switch, yang mempunyai kecepatan transfer data 10 , 100, atau $1000 \mathrm{Mbit} / \mathrm{s}$.

Selain teknologi Ethernet, saat ini teknologi 802.11 b atau biasa disebut Wi-fi juga sering digunakan untuk membentuk LAN. Tempattempat yang menyediakan koneksi LAN dengan teknologi Wi-fi biasa disebut hotspot. Pada sebuah LAN, setiap node atau komputer mempunyai daya komputasi sendiri, berbeda dengan konsep dump terminal. Setiap komputer juga dapat mengakses sumber daya yang ada di LAN sesuai dengan hak akses yang telah diatur. Sumber daya tersebut dapat berupa data atau 
perangkat seperti printer. Pada LAN, seorang pengguna juga dapat berkomunikasi dengan pengguna yang lain dengan menggunakan aplikasi yang sesuai.

Berdasarkan penelitian Anpryse, dkk (2013:129) mendapatkan fakta Wireless Access Point adalah adalah sebuah alat yang berfungsi untuk menyambungkan alat-alat wireless ke sebuah jaringan berkabel (wired network) menggunakan wifi. Wireless Access Point digunakan untuk membuat jaringan WLAN (Wireless Local Area Network) ataupun untuk memperbesar cakupan jaringan wifi yang sudah ada (menggunakan mode bridge). Access Point merupakan titik pusat jaringan wireless, alat ini memancarkan frekuensi radio untuk mengirimkan dan menerima data. Fungsi Wireless Access Point hampir sama dengan switch / hub dalam jaringan kabel yang memungkinkan banyak client terhubung ke jaringan. Hal yang mendukung perkembangan wireless adalah standarisasi teknologi komunikasi seluler generasi ketiga (3G), yang memungkinkan pengiriman data dalam kecepatan tinggi melalui jaringan Code.

Lingkungan merupakan kombinasi antara kondisi fisik yang mencakup sumber daya alam seperti manusia, tanah, air, udara, energy surya, flora dan fauna yang di atas tanah maupun di dalam lautan. Pada lingkungan ini yang mempengaruhi kecepatan transmit data ada berbagai macam yaitu: cuaca, jarak penerima dengan pemancar, tinggi bangunan disekitar penerima.

Perkembangan teknologi juga mempengaruhi kepada kecepatan transmit data karena semakin berkualitas teknologi yang kita gunakan maka kecepatan transmit datanya akan semakin tinggi, pada sisi pengguna juga mempengaruhi kecepatan transmit data seperti spesifikasi gadget atau laptop / komputer yang terlalu rendah juga dapat mempengaruhi kecepatan transmit data. Pada kecepatan transmit data sumber daya manusia juga mempengaruhi karena apabila orang yang melakukan settingan pada teknologi asal-asalan maka kecepatan transmit datanya tidak akan maksimal.

Ketika seseorang terkoneksi pada sebuah jaringan, maka secara otomatis terjadi hubungan antara dua atau lebih sistem yang terkoneksi. Sistem yang terkoneksi memiliki aturan (rule) yang memungkinkan koneksitas tersebut. Sekumpulan aturan-aturan yang memungkinkan adanya hubungan komunikasi tersebut disebut dengan protokol. Protokol dalam jaringan komputer terdapat dalam lapisan-lapisan (layers) suatu jaringan.

Dengan adanya teknologi informasi memang sangat membantu karyawan dalam proses kerja, akan tetapi masih terdapat interferensi yang terjadi dalam proses komunikasi data seperti error dalam pengiriman dan penerimaan data yang disebabkan oleh cuaca buruk, lambatnya proses pengiriman dan penerimaan data disebabkan oleh gangguan pada internet, dan tingkat keamanan data yang masih diragukan seperti tidak aktifnya enkripsi data.

Dimana tujuan dari penelitian ini adalah untuk mengetahui penggunaan Jaringan LAN pada PT Usda Seroja Batam

\section{Kajian Literatur}

Menurut Maslan (2012:2) jaringan komputer adalah sekumpulan dari komputer, printer, dan peralatan lainnya yang terhubung dalam satu kesatuan dan membentuk suatu sistem tertentu. Informasi bergerak melalui kabel atau tanpa kabel sehingga memnungkinkan pengguna jaringan komputer dapat saling bertukar informasi (data), mencetak data pada printer yang sama dan dapat secara simultan menggunakan program aplikasi yang sama.

Dalam jaringan komputer secara umum terdapat 2 media transmisi yaitu : media transmisi menggunakan kabel dan tanpa kabel. Media transmisi menggunakan kabel secara umum menggunakan kabel unshielded twisted pair (UTP), dan media transmisi tanpa kabel umumnya menggunakan gelombang mikro 2,4Ghz dan $5 \mathrm{Ghz}$.

Jaringan komputer juga memiliki topologi jaringan, secara umum topologi jaringan ada 6 yaitu : topologi bus, topologi star, topologi tree, topologi mesh dan topologi hybrid. Masingmasing topologi memiliki kelebihan dan 
kekurangan tinggal kita memilih mana yang cocok dengan kondisi yang kita alami.

Di dalam literatur masih sering terjadi kesulitan pemahaman dalam membedakan antara jaringan komputer dan sistem yang terdistribusi. Perbedaan utama yaitu bahwa sistem terdistribusi adalah kumpulan dari komputer yang berhubungan langsung dengan user, dapat digambarkan sebagai sebuah sistem berjalan. Sering kali lapisan dari software pada bagian sistem operasi yang disebut juga dengan middleware yang berfungsi untuk bertanggung jawab dalam penerapan model ini. Contoh dari sistem terdistribusi adalah World Wide Web, dimana semuanya terlihat seperti sebuah dokumen (Web page).

Menurut definisi (Sofana,2008:3), yang dimaksud dengan jaringan komputer adalah suatu himpunan interkoneksi sejumlah komputer autonomus. dijelaskan bahwa jaringan komputer adalah kumpulan beberapa komputer (dan perangkat lain seperti printer, hub, dan sebagainya) yang saling terhubung satu sama lain melalui media perantara.

Jaringan LAN merupakan jaringan milik pribadi yang biasanya digunakan di dalam sebuah gedung atau kampus yang berukuran sampai beberapa kilo meter. Jaringan LAN dapat dibedakan dari jenis jaringan lainnya berdasarkan tiga karakteristik: (1) ukuran, (2) teknologi transmisi dan (3) topologinya.

Jaringan LAN memiliki ukuran yang terbatas, yang berarti bahwa waktu transmisi pada keadaan terburuknya terbatas dan dapat diketahui sebelumnya. Dengan mengetahui keterbatasannya menyebabkan adanya kemungkinan untuk menggunakan jenis desain tertentu. Hal ini juga memudahkan manajemen jaringan.

Seperti halnya saluran pelanggan telepon yang dipakai di daerah pedesaan, jaringan LAN sering menggunakan teknologi transmisi kabel tunggal. Jaringan LAN tradisional beroperasi pada kecepatan mulai 10 sampai 100 Mbps dengan delay rendah (puluhan mikrosekon) dan mempunyai faktor kesalahan yang kecil. Jaringan LAN modern dapat beroperasi pada kecepatan yang lebih tinggi, sampai ratusan megabit per detik.

Wireless Local Area Network (WLAN) adalah teknologi LAN yang menggunakan frekuensi dan transmisi radio sebagai media penghantarnya, pada area tertentu, menggantikan fungsi kabel. Pada umumnya WLAN digunakan sebagai titik distribusi di tingkat pengguna akhir, melalui sebuah atau beberapa perangkat yang disebut dengan Access Point (AP), yang berfungsi mirip hub dalam terminologi jaringan kabel ethernet. Di tingkat backbone, sejumlah AP tersebut tetap dihubungkan dengan media kabel. WLAN dimaksudkan sebagai solusi alternatif media untuk menjangkau pengguna yang tidak terlayani oleh jaringan kabel, serta untuk mendukung pengguna yang sifatnya bergerak atau berpindah-pindah (mobilitas).

Dengan Performa dan keamanan yang dapat diandalkan, pengembangan jaringan wireless LAN menjadi tren baru pengembangan jaringan menggantikan janringan wired atau jaringan penuh kabel. Solusi dari pengembangan wireless LAN dapat mencakup sebuah kawasan rumah, kantor kecil, perusahaan hingga ke area-area public.

Tekhnologi wireless yang banyak digunakan saat ini adalah standar $802.11 \mathrm{~b}$ yang disebut wireless fidelity atau wi-fi. Wi-Fi merupakan pembahasaan dari jeratan kebel, sehingga penggunaan jaringan dapat melakukan koneksi jaringan dimanapun, baik indoor maupun outdoor, dalam range tertentu.

Beberapa komponen jaringan lokal adalah sebagai berikut:

a. Workstation, merupakan node atau host yang berupa suatu sistem komputer.

b. Server, Perangkat keras (hardware) yang berfungsi untuk melayani jaringan dan workstation yang terhubung pada jaringan tersebut. Pada umumnya sumberdaya (resources) seperti printer, disk, dan sebagainya yang hendak digunakan secara bersama oleh para pemakai di workstation berada dan bekerja pada server. 
c. Link, Workstation dan server tidak dapat berfungsi apabila peralatan tersebut secara fisik tidak terhubung..

d. Network Interface Card (NIC) , Suatu workstation tidak dihubungkan secara langsung dengan kabel jaringan ataupun tranceiver cable, tetapi melalui suatu rangkaian elektronika yang dirancang khusus untuk menangani network protocol yang dikenal dengan Network Interface Card (NIC).

e. Network Software, Tanpa adanya software jaringan maka jaringan tersebut tidak akan bekerja sebagaimana yang dikehendaki.

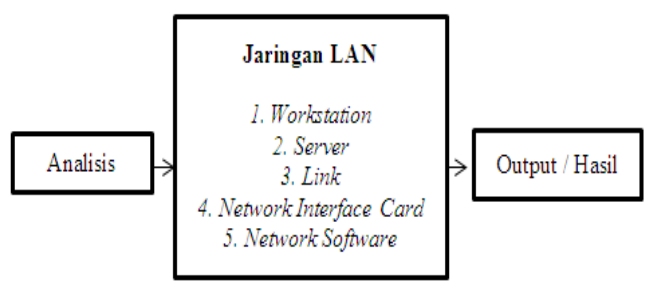

Gambar 1. Kerangka Pemikiran

\section{Metode Penelitian}

Adapun desain penelitian yang merupakan alur dalam penelitian ini dapat dijelaskan pada gambar (scheme) berikut ini:

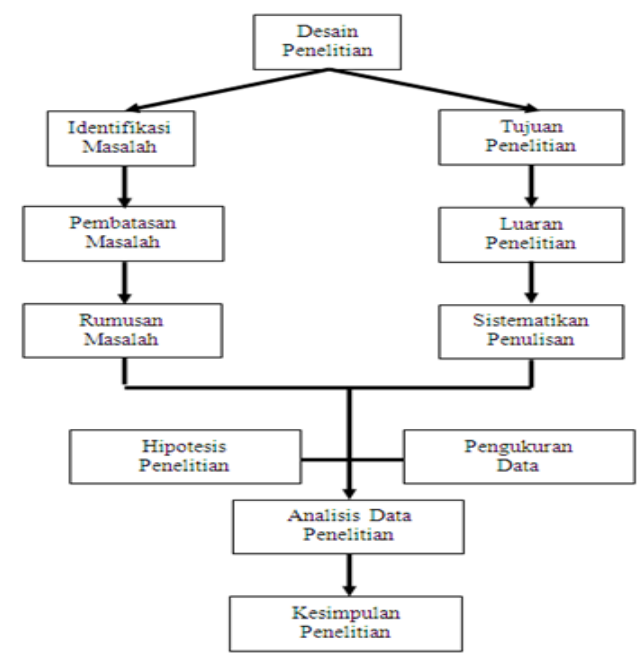

Gambar 2. Desain Penelitian

Populasi dalam penelitian ini adalah pengguna jaringan LAN pada PT Usda Seroja Batam. Dimana sampel dalam penelitian ini adalah menggunakan teknik quota sampling yang berarti sampel yang digunakan merupakan jumlah yang dibutuhkan oleh peniliti dan peneliti menetapkan jumlah sampel sebanyak 100 orang pengguna jaringan LAN pada PT Usda Seroja Batam. Dan jumlah karyawan sebanyak 226 karyawan pada PT Usda Seroja Batam. Dengan menggunakan teknik pengumpulan data dengan koesioner dan metode analisis deskriptif verifikatif.

Tabel 1. Jumlah Karyawan PT Usda Seroja

\begin{tabular}{|c|c|c|}
\hline No & $\begin{array}{c}\text { Status } \\
\text { Karyawan }\end{array}$ & $\begin{array}{c}\text { Jumlah } \\
\text { (Org) }\end{array}$ \\
\hline 1 & Permanen & 190 \\
\hline 2 & Kontrak & 36 \\
\hline Total & \multicolumn{2}{|c|}{} \\
\hline
\end{tabular}

Sumber: PT Usda Seroja(2017)

Dalam penelitian ini menggunakan analisis deskriptif yang digunakan untuk menganalisa data dengan cara mendeskripsikan atau menggambarkan data yang telah terkumpul sebagaimana adanya tanpa bermaksud membuat kesimpulan yang berlaku untuk umum atau generalisasi.

Dalam penelitian ini menggunakan skala Likert untuk memperoleh skor penilaian dengan nilai skor yang digunakan 5,4,3,2,1. Skor terendah dapat diperoleh melalui hasil perhitungan bobot terendah dikalikan dengan jumlah sampel, sedangkan skor tertinggi dapat diperoleh melalui bobot tertinggi dikalikan dengan jumlah sampel.

Tabel 2. Rentang Skala

\begin{tabular}{|c|c|}
\hline Rentang Skala & Kriteria \\
\hline $100-180$ & $\begin{array}{c}\text { Sangat Tidak } \\
\text { Setuju }\end{array}$ \\
\hline $181-261$ & Tidak Setuju \\
\hline $262-342$ & Tidak Tahu \\
\hline $343-423$ & Setuju \\
\hline $424-504$ & Sangat Setuju \\
\hline
\end{tabular}

Sumber: Data Diolah Sendiri, 2017

\section{Hasil Penelitian}


Berikut adalah uraian tentang hasil dan pembahasan yang antara lain adalah sebagai berikut:

Responden dalam penelitian ini adalah karyawan pengguna jaringan pada PT Usda Seroja Batam sebanyak 100 responden. Berdasarkan kuesioner yang telah diisi oleh responden, maka diperoleh data berupa identitas, identitas tersebut dijadikan sebagai profil responden.

Tabel 3. Profil Responden berdasarkan Jenis Kelamin

\begin{tabular}{|l|c|c|}
\hline Jenis Kelamin & $\begin{array}{l}\text { Jumlah } \\
\text { (Orang) }\end{array}$ & Persen \\
\hline Perempuan & 23 & 23.0 \\
\hline Laki-laki & 77 & 77.0 \\
\hline Total & 100 & 100.0 \\
\hline
\end{tabular}

Tabel 4. Profil Responden berdasarkan Umur

\begin{tabular}{|l|c|c|}
\hline Umur & Jumlah & Persen \\
\hline$<30$ & 75.0 & 75.0 \\
\hline$>30$ & 25.0 & 25.0 \\
\hline Total & 100.0 & 100.0 \\
\hline
\end{tabular}

Tabel 5. Profil Responden berdasarkan Pendidikan

\begin{tabular}{|l|c|c|}
\hline Pendidikan & Jumlah & Persen \\
\hline SMA & 75.0 & 75.0 \\
\hline Diploma & 10.0 & 10.0 \\
\hline S1 & 12.0 & 12.0 \\
\hline S2 & 3.0 & 3.0 \\
\hline Total & 100.0 & 100.0 \\
\hline
\end{tabular}

Penelitian ini bertujuan untuk mengetahui seberapa besar persepsi dari pengguna http://ejournal.upbatam.ac.id/index.php/cbis bagaimana kecepatan akses data pada jaringan di PT Usda Seroja Batam.. Untuk menjawab permasalahan tersebut, peneliti melakukan analisis deskriptif. Berdasarkan data yang diperoleh melalui angket / kuesioner, selanjutnya akan diolah dengan program statistik yaitu statistical package for the social science (SPSS) release 21. Adapun langkah awal untuk menentukan hasil penelitian adalah dengan melakukan analisis deskriptif.

Tabel 6. Hasil Analisis Deskriptif Variabel Jaringan LAN

\begin{tabular}{|c|c|c|c|}
\hline $\mathrm{N}$ & Pernyataan & $\begin{array}{l}\text { Total } \\
\text { Skor }\end{array}$ & $\begin{array}{c}\text { Kont } \\
\text { ribusi } \\
06\end{array}$ \\
\hline 1 & $\begin{array}{l}\text { Worktation yang digurakan } \\
\text { berupa host atan node pada auatu } \\
\text { aistem komputer. }\end{array}$ & 403 & 16.12 \\
\hline 2 & $\begin{array}{l}\text { Perangkat keras (hovdivare) yang } \\
\text { berfingai untul melayani jaringan. } \\
\text { dan worktation berada dan belkerja } \\
\text { pada aerver. }\end{array}$ & 397 & 15.88 \\
\hline 3 & $\begin{array}{l}\text { Worktation dan aerver tidak dapat } \\
\text { berfungai apabila peralatan teraebut } \\
\text { aecara fisik tidak terhubung. }\end{array}$ & 417 & 16.68 \\
\hline 4 & 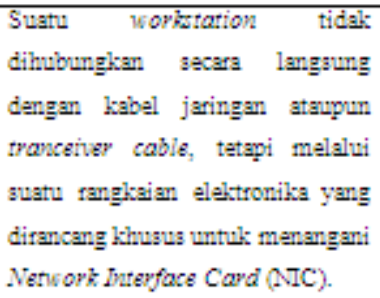 & 413 & 16.52 \\
\hline 5 & $\begin{array}{l}\text { Tarpa adanya softucare jaringan } \\
\text { maka jaringan teraebut tidak akan } \\
\text { belkerja gebagaimana yang } \\
\text { dikehendaki. }\end{array}$ & 401 & 16.04 \\
\hline \multicolumn{2}{|c|}{ Total Skor } & 2031 & 81.24 \\
\hline & Total Skor Ideal & 2500 & \\
\hline & 1 & Workt: & 403 \\
\hline
\end{tabular}

Tabel 7. Hasil Uji Validitas Jaringan LAN 


\begin{tabular}{|c|c|c|c|}
\hline \multicolumn{4}{|c|}{ Jaringan LAN } \\
\hline Pernyataan & $\begin{array}{c}\text { r- } \\
\text { hitung }\end{array}$ & r-tabel & Keterangan \\
\hline X1 & 0.537 & 0,195 & Valid \\
\hline X2 & 0.552 & 0,195 & Valid \\
\hline X3 & 0.576 & 0,195 & Valid \\
\hline X4 & 0.495 & 0,195 & Valid \\
\hline X5 & 0.559 & 0,195 & Valid \\
\hline
\end{tabular}

Hasil pengujian validitas yang dilakukan pada variabel Jaringan LAN, seperti yang tertera dalam tabel 7 menunjukkan bahwa nilai Coreccted Item-Total $\mathrm{r}$ hitung $>\mathrm{r}$ tabel, menandakan semua pernyataan atau kuesioner yang diajukan bernilai valid atau dapat dilakukan pengujian selanjutnya.

Tabel 8. Hasil Uji Reliabilitas Jaringan LAN

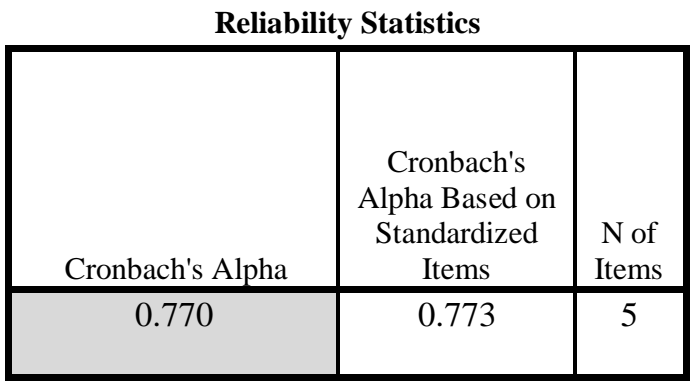

Nilai Cronbach's Alpha adalah 0,773 > 0,70 menunjukkan reliabilitas atau construck dari variabel Jaringan LAN tinggi. Berdasarkan kriteria seluruh $\mathrm{N}$ of Items 5 pernyataan dinyatakan reliable, artinya terdapat konsistensi jawaban responden atas 5 pernyataan kuesioner yang diajukan pada variabel jaringan LAN.

Pernyataan responden mengenai penggunaan jaringan LAN diperoleh nilai konstribusi sebesar 83.95\% yang berarti bahwa nilai kecepatan akses data dalam jaringan bagi karyawan PT Usda Seroja Batam adalah 81.24 \% dari yang diharapakan. Dimana total skor ideal sebesar 2000 dan rata-rata skor sebesar 406,2. Mengacu pada tabel 2 rentang skala, Rata-rata skor berada pada skala keempat 343 - 423 yaitu baik. Dengan demikian bahwa penggunaan jaringan LAN berjalan dengan baik pada PT Usda Seroja Batam.

\section{SIMPULAN DAN SARAN}

Berdasarkan hasil pengujian dan pembahasan yang telah diuraikan dapat ditarik kesimpulan bahwa berdasarkan hasil analisis deskriptif yang telah dilakukan dapat diperoleh gambaran bahwa kecepatan akses data pada PT Usda Seroja Batam sudah diterapkan dengan baik dengan besar konstribusi $83.95 \%$.

\section{DAFTAR PUSTAKA}

[1] Ariyus, D. dan A. K. R. R. (2008). Komunikasi Data (Edisi Satu). Yogyakarta: Andi.

[2] Harjono, S. R. (2013). Analisi Kecepatan Download pada GSM, Vol 2.

[3] Utomo, Priyo Eko. (2011). Membangun Jaringan Komputer dan Server Internet. Yogyakarta: Mediakom.

[4] Maslan, A. (2012). Belajar Cepat Teori, Praktek dan Simulasi Jaringan Komputer \& Internet. (T. Wangdra, Ed.) (Edisi Satu). Jakarta: Baduose Media.

[5] Rianse, U. \& A. (2008). Metodologi Penelitian Sosial dan Ekonomi: Teori dan Aplikasi (Edisi Satu). Bandung: Alfabeta.

[6] Sofana, I. (2008). Membangun Jaringan Komputer. Bandung: Informatika.

[7] Sofana, I. (2011). Teori dan Modul Praktikum Jaringan Komputer. Bandung: Modula.Kumar Soumen Pati and Asit Kumar Das. 2013. Constructing minimal spanning tree based on rough set theory for gene selection. Department of Computer Science/Information Technology.

[8] Sugiyono. (2009). Metode Penelitian Bisnis. Bandung: Alfabeta.

[9] Sugiyono. (2012). Metode Penelitian Manajemen (Edisi Satu). Bandung: Alfabeta.

[10] Sutarman. (2009). Pengantar Teknologi Informasi. Yogyakarta, Bumi Aksar.

[11] Widijanuarto, A. S. (2014). Jurus Kilat Membuat Jaringan Komputer, Jakarta Ti(Edisi satu, Dunia Komputer). 